\title{
ASSESSING TIDAL FLOOD UPON SOLAR SALT FARMING AREA IN NORTH PART OF JAVA USING HYDRODYNAMIC MODEL
}

\author{
A.W. Nirwansyah ${ }^{1,2}$, B. Braun ${ }^{1}$ \\ ${ }^{1}$ Institute of Geography, University of Cologne, 50923 Cologne, Germany - boris.braun@ uni-koeln.de \\ ${ }^{2}$ Department of Geography, Universitas Muhammadiyah Purwokerto, Banyumas,
}

Indonesia - anangwidi@ump.ac.id

\section{Commission VI, WG VI/4}

KEY WORDS: Impact, Tidal Flood, Solar Salt Farming, Hydrodynamic Model

\begin{abstract}
:
This study aims to assess the impact of high tide upon salt production areas in north part of Java, Indonesia. Single case in June 2016 was applied using MIKE 21 in salt production area of Cirebon. The inputs are tidal height records, bathymetry, digital elevation model (DEM) from Geospatial Information Agency (GIA), and wind data from OGIMET. Peak water level from tidal constituent is extracted from the simulation. The exposed that were generated from peak level of water elevation showed that tidal event has led to $82.9 \%$ of salt production area being inundated. West and east part are recorded as the most affected location due to this extreme event. The maximum water level has reached about $38 \mathrm{~cm}$ and covered more than $6,489.38$ ha during the tide. Whilst the accurate identification will provide valuable information for flood assessment upon marginal agriculture in coastal area.
\end{abstract}

\section{INTRODUCTION}

Tidal flooding presents amid the noticeable effects of global sea level rise nowadays (Dahl et al., 2017). Observed record of tidal inundation is still limited, yet are necessary to simulate the model for this typical natural hazard (Smith et al., 2012). Additionally, most of the flood model remains to focus on the cities consider the population increasing and their strategic role on economic (Bouwer et al., 2009; Ward et al., 2011). In the other side, the impact of flood in agriculture also plays a significant role in the agricultural flood disaster risk management (Wang, 2018). In individual level, flood impact in agriculture is simplified through coarse estimation as it results lower economic loss (Brémond and Grelot, 2013; Forster et al., 2008; Merz et al., 2010).

Another local economic activity in coastal area, solar salt production may faces coastal flooding (Prawira and Pamungkas, 2014). Solar salt works (salinas, salterns, salt fields) are manmade systems of interconnected ponds for the extraction of salt from seawater, by means of solar and wind evaporation (Korovessis and Lekkas, 2000). Tropical countries commonly manufacture the salt in coastal area using solar energy and evaporation process. This method requires relatively flat area with optimum access of salt water from the ocean for the input material, and relies on solar energy from the sun. Climate condition drives salt production capacity as it is dominated by conventional technology (Banday et al., 2015; Kurniawan, Tikkyrino; Azizi, 2012; Rahman, 2010). Currently, solar salt farming in north part of Java, Indonesia is impacted by tidal flood. Local media recorded that high tide flooding event in 2016 has inundated hundreds of hectares of salt ponds in Cirebon, as one of the major producer sites for salt in Indonesia (Lia, 2016; Metrotv, 2016).

A small number of coastal hazard management related studies has been done in Cirebon. Rositasari et al. (2011) approach vulnerability aspects in the coastal area of Cirebon by using a resistivity method to estimate potential damage using sea level rise (SLR) from Intergovernmental Panel for Climate Change (IPCC) scenarios on various land use. This study emanated saltwater intrusion as a baseline to calculate potential hazard in the future using general land value assumptions. Setyawan (2015) has depicted a model to estimate sea level rise implications on salt production activities in Cirebon using IPCC SLR scenarios. Landsat 7 ETM 3+ with 321 composite bands were also used to extract general figures of coastal land use in 2010. That research confirmed the possible loss of salt production areas due to coastal erosion. However, there is no specific evaluation of flood models in the traditional salt industry through original datasets and detailed topographic data.

A conceptual risk approach which uses Digital Elevation Model (DEM) to estimate flood hazard in the coastal area based on projected water levels is commonly practiced (van de Sande, Lansen, and Hoyng, 2012). DEMs are used to parameterize a 2D hydrodynamic flood simulation algorithm and predictions are compared with published flood maps and observed flood conditions (Sanders, 2007), or in general to build the relief (van Leeuwen, 2012). This data also defines the coastal inundation extent of tsunamis or storm surges (Webster and Stiff, 2008), and the loss of coastal areas due to sea level rise (Simpson et al., 2015).

This research mainly simulate tidal flood of post-event of June 2016 on solar salt production area. The hydrodynamic method is applied using MIKE 21 and analysed using GIS. Currently, further analysis of tidal flooding in the salt production area of Cirebon are not available. Finally, this study alternates higher precision of analysis on the distribution of tidal flooding in salt production areas. Moreover, this technique may also be implemented for the data-scarce region where coastal inundation dominantly controlled by the tidal cycle. 


\section{CONSTRUCTION OF THE METHOD}

\subsection{Study area}

This study is focused on salt production area in Cirebon, West Java. It is located $6^{\circ} 30^{\prime}-7^{\circ} 00^{\prime} \mathrm{S}$ and $108^{\circ} 40^{\prime}-108^{\circ} 48^{\prime} \mathrm{E}$ and lied along northern coast of Java. Along with agriculture, salt production is major economy of coastal community in Cirebon. The total salt ponds employ 7,819.32 ha and labour approximately 3,707 people, including pond owners, salt workers, and intermediaries (KKP, 2015; PSSDAL, 2010). Administratively, Cirebon is adjacent to the Java Sea, and by Indramayu in the north, Kuningan in the south, Central Java Province in the east, and Majalengka in the west. The Java Sea is mainly categorised as shallow water within nearly rectangular morphology, mean depth of $50 \mathrm{~m}$, length of $950 \mathrm{~km}$, and width of $440 \mathrm{~km}$ (Durand and Petit, 1995; Koropitan and Ikeda, 2008). The tidal range in the Java Sea is approximately 1.2-2 meter, with peak values around Surabaya, Madura, and Bali (ICCSR, 2010; Takagi et al., 2016).

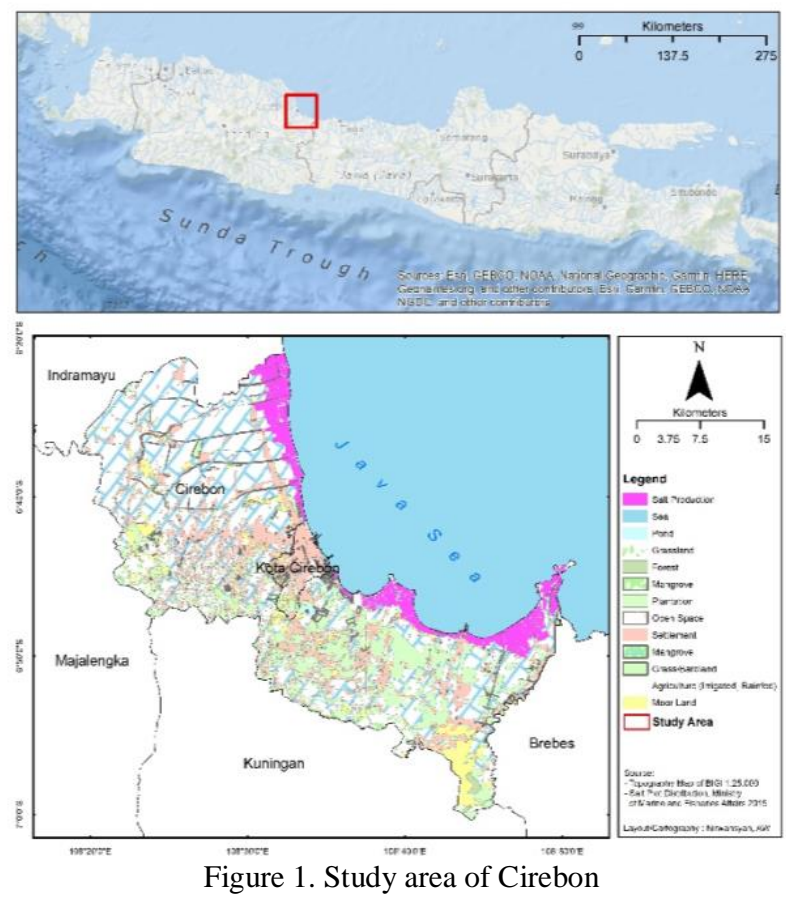

\subsection{Overview of the model}

Generally, we exploit hydrodynamic model to evaluate the afterevent flooding in 2016, which has been recorded widely in local media and mentioned by the local farmer during the fieldwork. We utilize DHI MIKE application as one of the most recognizable for hydrodynamic simulation including coastal flooding, storm surge, inland flooding and overflow (Nguyen, 2017; Qiao et al., 2018; Thambas, 2016). The simulation involves MIKE 21 Flexible Mesh (FM) to investigate the water dynamic condition in selected event. The simulation created 87,103 nodes and 170,501 elements which covered $11,515.20 \mathrm{~km}^{2}$ in Cirebon waters (Figure 2). We also used hourly tidal gauge data from Cirebon port. The classical harmonic analysis is used to represent the tidal forcing, and demonstrate the total of finite set in certain frequencies of sinusoids setting (Reforgiato et al., 2013). Thus results in nine tidal components $\left(M_{2}, S_{2}, N_{2}, K_{2}, K_{1}, O_{1}, P_{1}, M_{4}\right.$, and $M S_{4}$ ), resemble typical characteristic of tidal and its relation to the lunar and solar gravitation against seabed in shallow seas.

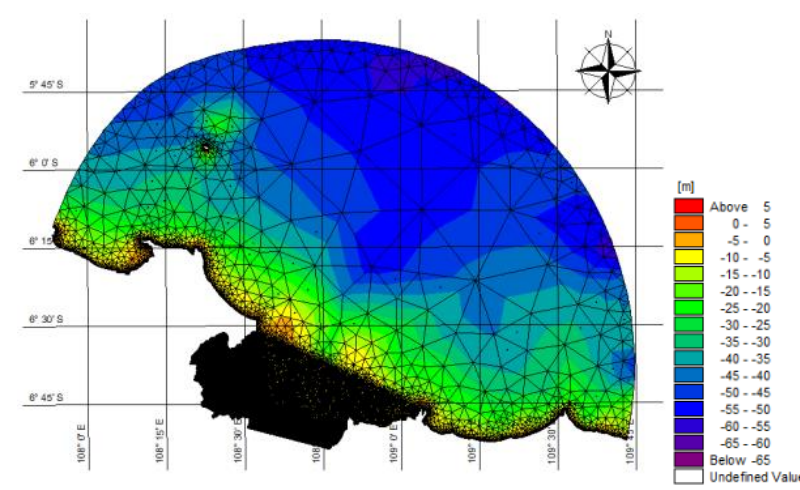

Figure 2. Unstructured grid and mesh in tidal simulation, located in Cirebon waters involves 87,103 nodes and 170,501 elements

\subsection{Data used}

Bathymetric information was generated from gridded national bathymetry of Indonesia (BATNAS) and provided by Indonesia Geospatial Information Agency (GIA) or (BIG: Badan Informasi Geospasial in Indonesian) with six arc-second resolutions (http://tides.big.go.id/DEMNAS/). We have also employed five surface topography datasets, referred as DEM from the same provider within 0.27 -arc second resolution. We engage wind factor using data from Jatiwangi station. The hourly wind data source is acquired from OGIMET website (https://www.ogimet.com/) included velocity and direction information. Flood and drying (FAD) platform in MIKE assists the water run-up simulation and deliver inundation process on selected period. A previous study of Thambas (Thambas, 2016), where $h_{d r y}=0.005 \mathrm{~m}$, flooding depth $h_{\text {flood }}=0.05 \mathrm{~m}$ and wetting depth $h_{\text {wet }}=0.1 \mathrm{~m}$ were recommended in the simulation and created an appropriate model for wave overtopping.

\subsection{Limitation of the model}

We limit the model through several circumstances. First, we define bottom friction coefficient based on Manning's approach as 40 for waters and 32 for land (Department of Environmental Protection, 2014). Meanwhile, the horizontal eddy viscosity is 0.28 (Nguyen, 2017). Secondly, this model does not involve the land use change and land subsidence as there were no significant change in salt production area and no records of vertical land motion in the particular area.

\section{RESULTS AND DISCUSSION}

Here, we match the MIKE simulation and the input from tidal gauge from local station in Cirebon to global tidal model TPXO9 as latest version of TPXO series (Green et al., 2018; Seifi et al., 2018). This model can be accessed on http://volkov.oce.orst.edu/tides/global.html. The TPXO has 1/6 resolution and suits for long track average data from T/P and Jason (Egbert and Erofeeva, 2002; Green et al., 2018). Temporarily, the tidal current velocity is verified using Tidal Model Driver (TMD). This free-source MATLAB tool predicts tide height and also currents (Padman, 2005). Here, verification points of the selected simulation are placed in Tawangsari, Pangenan, and Bungko. We estimated Pearson value (r) of the three locations with the general tidal model of TPXO9, and presented value of Root Mean Square (RMS) error to quantify statistical correlation. Moreover, the RMS error

$$
x_{R M S}=\sqrt{\left(\sum_{i=1}^{n} x_{i}^{2}\right) / n}
$$


where $x_{i}$ is the $i^{\text {th }}$ points to the chosen area, were calculated in the Cirebon waters. The overall locations verify excellent correlations between simulated outcomes, and those of TPXO9 and TMD. The correlation of simulation present in range $0.903-$ 0.908 and RMSE at 0.069-0.1 meter. Meanwhile $u$-velocity component in those three sample location shows a coefficient around $0.833-0.965$ with a RMSE of about $0.023-0.0196 \mathrm{~m} / \mathrm{s}$ and $v$-velocity is about $0.683-0.824$ with RMSE about $0.040-0.061$ $\mathrm{m} / \mathrm{s}$ (see Table 1 ).

\begin{tabular}{lccccccc}
\hline \multirow{2}{*}{ STA } & \multicolumn{2}{c}{ Height $(\zeta)$} & \multicolumn{2}{c}{$u$-velocity } & \multicolumn{2}{c}{$v$-velocity } \\
\cline { 2 - 8 } & $\mathrm{r}$ & $\begin{array}{c}\text { RMSE } \\
(\mathrm{m})\end{array}$ & $\mathrm{r}$ & $\begin{array}{c}\text { RMSE } \\
(\mathrm{m} / \mathrm{s})\end{array}$ & $\mathrm{r}$ & $\begin{array}{c}\text { RMSE } \\
(\mathrm{m} / \mathrm{s})\end{array}$ \\
\hline Tawangsari & 0.903 & 0.071 & 0.894 & 0.0196 & 0.715 & 0.061 \\
\hline Pangenan & 0.904 & 0.100 & 0.833 & 0.029 & 0.724 & 0.050 \\
\hline Bungko & 0.908 & 0.069 & 0.965 & 0.023 & 0.824 & 0.048 \\
\hline
\end{tabular}

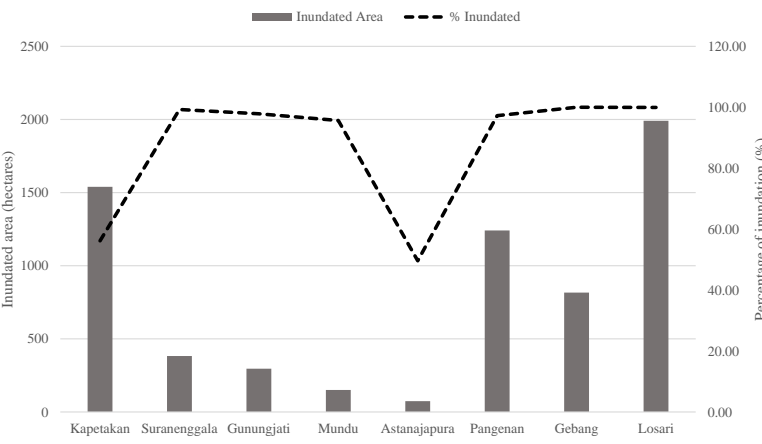

Figure 4. Distribution of flooding during peak of tide event in Cirebon in $2^{\text {nd }}$ June 2016 12:00 UTC

Coastal floods driven by tidal processes have a significant impact on the production. During the production period, floods can occur

Table 1 Correlation coefficient (r) and RMS Error between

MIKE simulation and TPXO9 for water level and velocity components from TMD

In the next step, we comprise wind datasets (within direction, and velocity) in the model. Here the simulation shows that there is minor difference in the tidal pattern due the relatively small effect of wind as velocity of wind dominantly emerged from the north with a maximum speed of $6.8 \mathrm{~m} / \mathrm{s}$ and mean velocity $0.81 \mathrm{~m} / \mathrm{s}$. Based on that, we suppose relatively calm-wind type has small impact on tidal floods along the coast. Here, velocity of the wind resolves a minimum correlation to the water level (Pearson value 0.1902-0.1905). Meanwhile, correlation values to tidal gauge observation 0.761 with RMSE of 0.134 meters (see Figure 3 ).

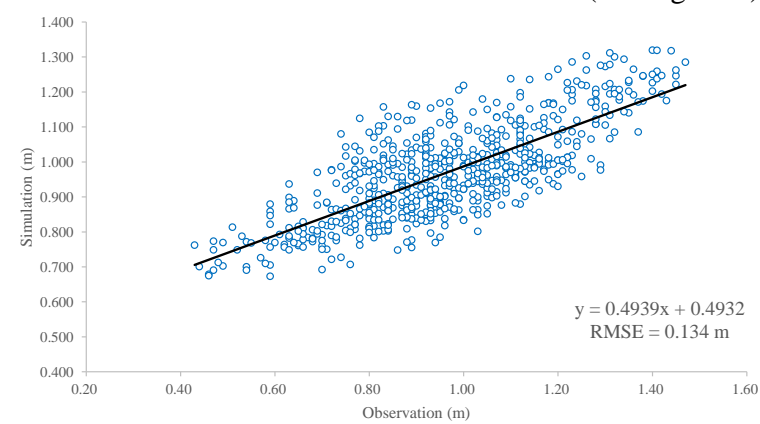

Figure 3. Scatterplot and RMS error of simulated surface water level with tide gauge observation in June 2016

\subsection{Maximum water level during simulation}

The simulation shows that tidal flood appeared in coastal area of Cirebon in 2016. Here GIS reclassifies the flood depth on each salt parcel as a single value of depth. The input of DEMNAS here was overlaid by grid data from MIKE simulation which previously exported by "Mike2Grid" feature.

Based on the simulation, surface elevation at the peak of tidal event in Cirebon is expected to be on $2^{\text {nd }}$ June 2016 12:00 UTC within $0.38 \mathrm{~m}$ height. Using detailed DEM, the submerged in solar salt production area is below 0.38 meters. From that, salt pond area in Losari district (east part) whereas 1,990.55 ha $(99.92 \%)$ area is inundated. Meanwhile, Gebang, which is located in the west part, also completely submerged within total area of 816.32 ha. In Kapetakan, around $56.15 \%$ (1,538.96 ha) is flooded. The middle section of area has also suffered from the inundation relatively lower due to its relatively higher elevation. The following Figure 4 draws the distribution of inundation in the peak of simulation period. $30-70 \mathrm{~cm}$ (Figure 5a). The inundation can stay for a few days before the water receded. Here, it has to be considered that higher inundation also need more time to recede, at the same time, extend the preparation process. In the west monsoon period (April-October) tidal occurrence increases and creates more problems in production process. In the rainy season, most of farmers do not work as salt farmers and choose to sell their stockpile from their warehouse (Figure $5 b$ ).
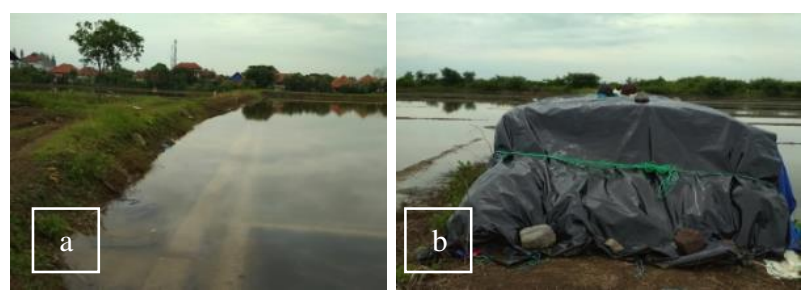

Figure 5. Flooded salt pond (a) and a salt stockpile of salt farm in Pangenan, Cirebon (own documentation)

\section{CONCLUSIONS AND FUTURE WORK}

This paper discusses hydrodynamic model to assess tidal inundation upon solar salt production area in northern part of Java. In this work, the model shows the distribution of tidal using maximum elevation of the water, extracted from the MIKE simulation. Here, the momentum can be identified as the input on the hazard mapping to obtain the exposed area inundated. From here, a method is expected to be developed to identify the tidal flood impact in various type of agriculture in the coastline using local meteorological condition, especially tidal records from local tidal station and wind data.

\section{ACKNOWLEDGEMENTS}

This project has been part of doctoral research at the Institute of Geography, University of Cologne, Germany, supported by Indonesia Endowment Fund for Education (LPDP) and Universitas Muhammadiyah Purwokerto, Indonesia. Part of the data used for this paper was made possible through the support of the National Geospatial Agency (BIG), Indonesia, and the Ministry of Marine and Fisheries Affairs (KKP).

\section{REFERENCES}

Banday, U., Bhat, A.H., Sharma, K.C., Banday, U.J., 2015. Impact of Climatic Variability on Salt Production in Sambhar Lake, a Ramsar Wetland of Rajasthan, India. Middle-East J. Sci. Res. 23, 2060-2065. 
https://doi.org/10.5829/idosi.mejsr.2015.23.09.95224

Bouwer, L.M., Bubeck, P., Wagtendonk, A.J., Aerts, J.C.J.H., 2009. Inundation scenarios for flood damage evaluation in polder areas. Nat. Hazards Earth Syst. Sci. 9, 1995-2007. https://doi.org/10.5194/nhess-9-1995-2009

Brémond, P., Grelot, F., 2013. Review Article: Economic evaluation of flood damage to agriculture - Review and analysis of existing methods. Nat. Hazards Earth Syst. Sci. 13, 2493-2512. https://doi.org/10.5194/nhess-13-24932013

Dahl, K.A., Fitzpatrick, M.F., Spanger-Siegfried, E., 2017. Sea level rise drives increased tidal flooding frequency at tide gauges along the U.S. East and Gulf Coasts: Projections for 2030 and 2045. PLoS One 12, e0170949. https://doi.org/10.1371/journal.pone.0170949

Department of Environmental Protection, 2014. Rebuild by Design-Hudson River Project Feasibility Study Report. New Jersey.

Durand, J.R., Petit, D., 1995. The Java Sea Environment, in: Nurhakim, S. (Ed.), Biodynex: Biology, Dynamics and Exploitation of the Small Pelagig Fishes in the Java Sea. Agency for Agricultural Research and Development, Jakarta, pp. 15-38.

Egbert, G., Erofeeva, S.Y., 2002. Efficient Inverse Modeling of Barotropic Ocean Tides. Am. Meteorogical Soc. 19, 183 204.

Forster, S., Kuhlmann, B., Lindenschmidt, K.E., Bronstert, A., 2008. Assessing flood risk for a rural detention area. Nat. Hazards Earth Syst. Sci. 8, 311-322. https://doi.org/10.5194/nhess-8-311-2008

Green, J.A.M., Bowers, D.G., Byrne, H.A.M., 2018. A mechanistic classification of double tides. Ocean Sci. Discuss. 1, 1-15. https://doi.org/10.5194/os-2018-72

ICCSR, 2010. Scientific Basis: Analysis and Projection of Sea Level Rise and Extreme Weather Event. Jakarta.

KKP, 2015. Salt Production of Indonesia (in Bahasa). Jakarta.

Koropitan, A.F., Ikeda, M., 2008. Three-dimensional modeling of tidal circulation and mixing over the Java Sea. J. Oceanogr. 64, 61-80. https://doi.org/10.1007/s10872008-0005-5

Kurniawan, Tikkyrino; Azizi, A., 2012. Climate change impact on salt ponds farmers in Sampang and Sumenep districts. J. Masy. dan Budaya 14, 499-518.

Lia, E., 2016. Puluhan Ribu Ton Garam di Cirebon Tersapu Banjir Rob page-2 : Okezone News [WWW Document]. okezone.com. URL https://news.okezone.com/read/2016 /06/17/525/1418255/puluhan-ribu-ton-garam-di-cirebontersapu-banjir-rob?page=2 (accessed 6.10.19).

Merz, B., Kreibich, H., Schwarze, R., Thieken, A., 2010. Review article "Assessment of economic flood damage." Nat. Hazards Earth Syst. Sci. 10, 1697-1724. https://doi.org/10.5194/nhess-10-1697-2010

Metrotv, 2016. 700 Hectares of Salt Pond in Cirebon Submerged Coastal Flood (in Bahasa) [WWW Document]. metrotvnews.com. URL http://m.metrotvnews.com/jabar/peristiwa/JKR4MYQb700-hektare-tambak-garam-di-cirebon-terendam-banjirrob (accessed 9.29.17).

Nguyen, T., 2017. An Evaluation of Coastal Flooding Risk due to Storm Surge under Future Sea Level Rise Scenarios in Thua Thien Hue Province, Vietnam. Texas Tech University.

Padman, L., 2005. Tide Model Driver ( TMD ) Manual. Arctic $1-12$.

Prawira, M.P., Pamungkas, A., 2014. Mitigasi Kawasan Rawan Banjir Rob di Kawasan Pantai Utara Surabaya. J. Tek. POMITS 3, 160-165.
PSSDAL, 2010. Peta Lahan Garam Indonesia. PSSDAL BAKOSURTANAL, Cibinong.

Qiao, H., Zhang, M., Jiang, H., Xu, T., Zhang, H., 2018. Numerical study of hydrodynamic and salinity transport processes in the Pink Beach wetlands of the Liao River estuary, China. Ocean Sci. 14, 437-451. https://doi.org/10.5194/os-14-437-2018

Rahman, M.A., 2010. Salt is bitter: Salinity and livelihood in a Bangladesh village. Int. J. Interdiscip. Soc. Sci. 5, 317 330 .

Reforgiato, D., Zavarella, V., Consoli, S., 2013. A survey on tidal analysis and forecasting methods for tsunami Detection. Sci. Tsunami Hazards 1-58.

Rositasari, R., Setiawan, W.B., Supriadi, I.H., Prayuda, B., 2011. Coastal Vulnerability Prediction To Climate Change: Study Case in Cirebon Coastal Area. J. Ilmu dan Teknol. Kelaut. Trop. 3, 52-64.

Seifi, F., Deng, X., Andersen, O.B., 2018. Accuracy assessment of recent empirical and assimilated tidal models for the Great Barrier Reef region. Eur. Geosci. Union.

Setyawan, W.B., 2015. Potensi Dampak Kenaikan Muka Laut terhadap Dataran Pesisir dan Aktifitas Produksi Garam di Kawasan Pesisir Mundu, Kabupaten Cirebon. J. Segara 7, 42-56.

Smith, R.A.E., Bates, P.D., Hayes, C., 2012. Evaluation of a coastal flood inundation model using hard and soft data. Environ. Model. Softw. 30, 35-46. https://doi.org/10.1016/j.envsoft.2011.11.008

Takagi, H., Esteban, M., Mikami, T., Fujii, D., 2016. Projection of coastal floods in 2050 Jakarta. Urban Clim. 17, 135145. https://doi.org/10.1016/j.uclim.2016.05.003

Thambas, A.H., 2016. Inundation risk analysis of the storm surge and flood for the Ariake Sea coastal disaster management. Saga University.

Wang, Y., 2018. Quantitative Agricultural Flood Risk Assessment Using Vulnerability Surface and Copula Functions. https://doi.org/10.3390/w10091229

Ward, P.J., Marfai, M.A., Yulianto, F., Hizbaron, D.R., Aerts, J.C.J.H., 2011. Coastal inundation and damage exposure estimation: a case study for Jakarta. Nat. Hazards 56, 899 916. https://doi.org/10.1007/s11069-010-9599-1 